Mеталлофиз. новейшие технол. / Metallofiz. Noveishie Tekhnol. @ 2018 ИМФ (Институт металлофизики 2018, т. 40, № 5, сc. 625-635 / DOI: 10.15407/mfint.40.05.0625 им. Г. В. Курдюмова НАН Украины) Оттиски доступны непосредственно от издателя

Фотокопирование разрешено только

Напечатано в Украине.

в соответствии с лицензией

PACSnumbers: 61.05.cp, 62.23.Pq, 68.37.Lp, 68.65.Pq, 75.60.Ej, 75.75.Cd, 81.05.ue

\title{
Synthesis and Magnetic Characteristics of N-Co Nanocomposites
}

\author{
O. M. Lisova, M. V. Abramov, S. M. Makhno, and P. P. Gorbyk \\ O. O. Chuiko Institute of Surface Chemistry, N.A.S. of Ukraine, \\ 17 General Naumov Str., \\ UA-03164 Kyiv, Ukraine
}

The single-domain nanoparticles of NiCo, NiCo on the surface of graphene $(\mathrm{NiCo} @ \mathrm{GNP})$ and $\mathrm{NiCo}$ on the surface of silica dioxide $\left(\mathrm{NiCo} @ \mathrm{SiO}_{2}\right)$ are synthesized. Their crystalline structure, surface morphology and magnetic characteristics of nanoparticle are investigated. It is shown that the magnetization curve of the nanoparticles ensembles in the form, which is distinctive for superparamagnets, and its calculations within the framework of the Langevin's paramagnetism theory are satisfactorily consistent with the experimental results. The laws of particle size distribution in ensembles are established using the method of magnetic granulometry.

Key words: nanocomposites, nanoparticles, graphene, magnetic properties, superparamagnets.

Синтезовано однодоменні наночастинки $\mathrm{NiCo}$, NiCo на графеновій поверхні (NiCo@ГНП) та $\mathrm{NiCo} \mathrm{на} \mathrm{поверхні} \mathrm{діоксиду} \mathrm{силіцію}\left(\mathrm{NiCo} @ \mathrm{SiO}_{2}\right)$. Досліджено їхні кристалічну структуру, морфологію поверхні та магнетні характеристики ансамблів наночастинок. Показано, що крива магнетованости ансамблів наночастинок має форму, характерну для суперпарамагнетиків, а її розрахунки в рамках Ланжевенової теорії парамагнетизму задовільно узгоджуються з експериментальними результатами. Методою магнетної гранулометрії встановлено закони розподілу частинок за розмірами в ансамблях.

Ключові слова: нанокомпозити, наночастинки, графен, магнетні властивості, суперпарамагнетики.

Corresponding author: Oksana Miroslavivna Lisova

E-mail: oksana.garkusha@gmail.com

Citation: O. M. Lisova, M. V. Abramov, S. M. Makhno, and P. P. Gorbyk, Synthesis and Magnetic Characteristics of N-Co Nanocomposites, Metallofiz. Noveishie Tekhnol., 40, No. 5: 625-635 (2018), DOI: 10.15407/mfint.40.05.0625. 
Синтезированы однодоменные наночастицы $\mathrm{NiCo}$, NiCo на поверхности графена (NiCo@GNP) и $\mathrm{NiCo}$ на поверхности диоксида кремния $\left(\mathrm{NiCo@SiO}{ }_{2}\right)$. Исследованы кристаллическая структура, морфология поверхности и магнитные свойства нанокомпозитов. Показано, что кривая намагниченности ансамблей наночастиц имеет форму, характерную для суперпарамагнетиков; её расчёты в рамках теории парамагнетизма удовлетворительно согласуются с экспериментальными результатами. Методом магнитной гранулометрии установлены законы распределения частиц по размерам в ансамблях.

Ключевые слова: нанокомпозиты, наночастицы, графен, магнитные свойства, суперпарамагнетики.

(Received March 1, 2018)

\section{INTRODUCTION}

Bimetallic nanocomposites (BNCs) containing nanoparticles (NP) of organic and inorganic materials have been attracting considerable attention of specialists in recent years $[1,2]$ due to a large number of possible applications [3, 4]. Prominent areas for the using of such structures are catalysis and electrocatalysis [5, 6]; in electronics, BNCs are used as electrode materials for solar and fuel cells [7, 8], electric and biosensors [9, 10], as corrosion-resistant materials and much more. The importance of searching for new methods of obtaining and researching $\mathrm{BNCs}$ is due to their multifunctionality, the possibility of a unique combination of the properties of many materials in one [4]. They acquire better catalytic, thermal, optical, electrical, and magnetic properties as compared to monometallic and bimetallic particles without a matrix. Consequently, the presence of a matrix not only plays the role of a substrate, but also is a functionally active element [11]. Composites are obtained on various inorganic (kaolin, zeolites and zirconium) and organic (artificial and natural polymers, graphite derivatives) matrices $[1,6,12]$.

In recent years, various methods for obtaining bimetallic BNCs have been developed, the synthesis of which is carried out by spraying methods [13, 14], glow discharge [15], pulsed laser ablation [16], reversed micelles [17], thermal decomposition [18], chemical recovery from a solution [19, 20]. Most often, bimetallic LFs are obtained by simultaneous restoration of two metal ions in conditions of stabilization of the chemical composition, size, and shape of particles. BNCs have different forms; they exist in the form of alloys or contact agglomerates, such as kernel-shell, etc.

Particular attention is paid to the magnetic properties of BNCs containing ferromagnetic NPs on carbon-containing matrices, which are investigated for creating water-purifying filters [21, 22], rechargeable 
batteries, various sensors [4], protective materials from corrosion and deterioration [11] and electromagnetic waves [23] and others.

The purpose of the work is to study the structural and magnetic properties of ferromagnetic nanoparticles NiCo, NiCo@GNP and Ni$\mathrm{Co} @ \mathrm{SiO}_{2}$ nanocomposites.

\section{MATERIALS AND METHODS}

Graphene nanoplates (GNP) are obtained by electrochemical deposition in an electrolyte $(\mathrm{KOH})$ of a low concentration at a current passing to 60 $\mathrm{mA} / \mathrm{cm}^{2}$. Electrodes were placed between polypropylene fabric filters for the separation of large graphite particles from nanosized ones. GNPs are stored in the form of a suspension with a mass concentration of graphene $2 \%$ and $\mathrm{pH}=12$. The NiCo particles were obtained by the method of chemical precipitation from a solution of hydrazine hydrate of nickel and cobalt carbonates [24] at a temperature of $350 \mathrm{~K}$. The technique was modified for the purpose of synthesis of NiCo@GNP composites, coprecipitation of a solution of carbonates and a suspension of graphene was prepared at a boiling point of hydrazine hydride at a mass ratio of 9:1 components. The presence of $\mathrm{KOH}$ in a suspension of graphene created favourable conditions for the synthesis of metal particles. GNPs play the role of crystallization centres as well as contribute to the stabilization of the size and chemical composition of nanoparticles.

For the synthesis of $\mathrm{NiCo} @ \mathrm{SiO}_{2}$ composites, a $\mathrm{SiO}_{2}$ suspension had been previously prepared by mixing tetraethoxysilane with ethyl alcohol and ammonium hydroxide in a ratio of 1:20:10. The slurry was added to a $\mathrm{Ni}$ and Co carbonates solution in hydrazine hydrate.

$\mathrm{X}$-ray diffraction analysis was performed by powder diffractometry on a DRON-4-07 diffractometer while the emission of an anode line $\mathrm{Cu} K_{\alpha}$ with a nickel filter in the reflected beam at the geometry of the Breguet-Bretagne shooting. The morphology of the specimens was studied using a JEOL JEM-1230 transmitted electronic microscope.

The hinges of the magnetic moment of the specimens were measured using a laboratory vibration magnetometer at a room temperature. The description of the installation and the method of measurement are described in [25]. Specially prepared, demagnetized specimens were measured. For comparison, a test sample of nickel was used. The measurement error of the specific saturation magnetization $\left(\sigma_{s}\right)$ relative to the tested sample did not exceed $\pm 2.5 \%$.

\section{RESULTS AND DISCUSSION}

The electron-microscopy studies revealed the presence of nanometersize particles in all three understudied systems. It is shown that, on the 


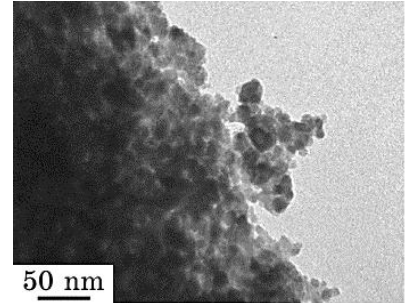

$a$

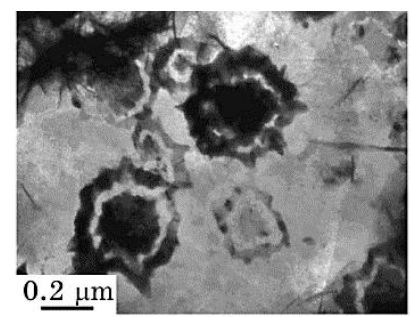

$b$

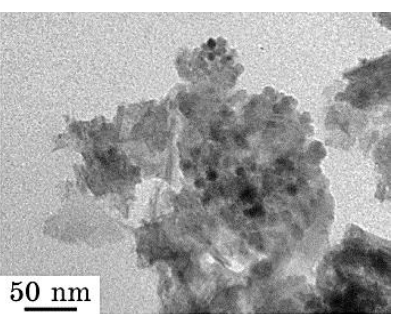

c

Fig. 1. PEM images of the NiCo (a), NiCo@GPN $(b), \mathrm{NiCo@SiO}{ }_{2}(c) \mathrm{NP}$.

surface of the GNP, there are metal particles in the size range $\cong 20-$ $200 \mathrm{~nm}$ (Fig. 1, b); in more detailed images of graphene film, metal particles of $20 \mathrm{~nm}$ can be observed. Large particles are probable to be agglomerates consisting of small ones [24].

The results of the x-ray diffraction (Fig. 2) analysis indicated the presence of phases of GNP, nickel, cobalt and the absence of reflexes of the incoming carbonates. Thus, peaks of $22.4^{\circ}$ and $31.3^{\circ}$ can be related to the presence of graphene structures in samples, and a low-intensity band of $27.1^{\circ}$ corresponds to a crystalline lattice of graphite. Particles of nickel may correspond to peaks of $44.9^{\circ}$-octahedral (111), 52.2 and $91.8^{\circ}$ - cubic syngony.

The cobalt crystalline lattice of a cubic syngony corresponds to peaks of $52.2^{\circ}(111), 61.2^{\circ}(200), 91.8^{\circ}(220)$, hexagonal-55.9 ${ }^{\circ}(101)$. Consequently, the peaks of $52.2^{\circ}$ and $91.8^{\circ}$ may indicate the presence of bime-

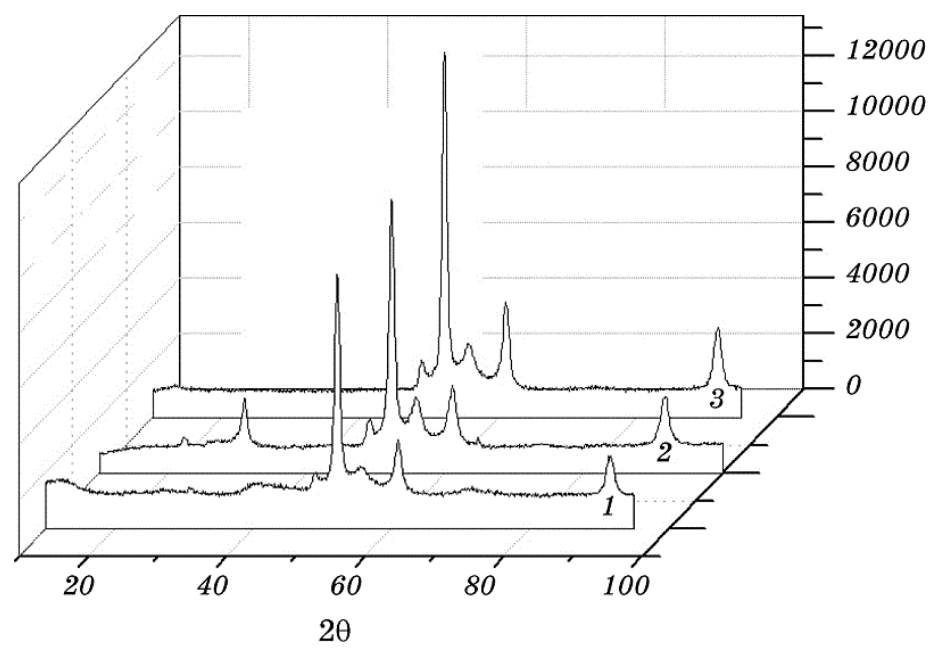

Fig. 2. The diffraction pattern of the $\mathrm{NiCo}(1), \mathrm{NiCo@GNP} \mathrm{(2)} \mathrm{and} \mathrm{NiCo} @ \mathrm{SiO}_{2}$ (3) samples. 
TABLE 1. Statistical parameters of low-frequency NiCo and NiCo@GNP, Ni$\mathrm{Co} @ \mathrm{SiO}_{2}$ structures.

\begin{tabular}{c|c|c|c|c|c}
\hline Pattern & $N$ & $<D>, \mathrm{nm}$ & $\sigma_{D}, \mathrm{~nm}$ & $<\ln D>$ & $\sigma_{\ln D}$ \\
\hline NiCo & 62 & 9.96991 & 3.71358 & 2.24052 & 0.34173 \\
$\mathrm{NiCo@ \Gamma H \Pi}$ & 63 & 23.33829 & 8.84181 & 3.08827 & 0.34629 \\
$\mathrm{NiCo} @ \mathrm{SiO}_{2}$ & 64 & 8.67567 & 3.36113 & 2.08959 & 0.38353 \\
\hline
\end{tabular}

$N$-the amount of particles, $<D>$ - the average of the NP diameter, $\sigma_{D}$-the standard deviation of the NP diameter, $<\ln D>$ - the average of the logarithm of the NP diameter, $\sigma_{\ln D}$-standard deviation of the logarithm of the NP diameter.

tallic particles of NiCo with a cubic crystal lattice (200) [13]. The size of crystallites, calculated by Scherrer's equation, is $15-20 \mathrm{~nm}$.

The parameters of the basal cell NiCo and NiCo@GNP and Ni$\mathrm{Co} @ \mathrm{SiO}_{2}$ bands obtained by statistical processing of the PEM images of the corresponding samples are given in Table 1.

The size distribution of superparamagnetic particles can be determined by measuring the magnetization curve $M(H)$, pronounced by the Langevin function [26], we assume that all particles have a spherical shape without interaction.

The normal distribution is determined by the Gauss equation:

$$
p\left(d, M_{d}, \sigma_{d}\right)=\frac{1}{\sigma_{d} \sqrt{2 \pi}} e^{-\frac{\left(d-M_{d}\right)^{2}}{2 \sigma_{d}^{d}}},
$$

where $M_{d}$ and $\sigma_{d}$ are expected value and standard deviation of the NP diameter, respectively.

The lognormal distribution of particles in diameters is determined by the equation:

$$
p\left(\ln d, M_{\ln d}, \sigma_{\ln d}\right)=\frac{1}{d \sigma_{\ln d} \sqrt{2 \pi}} e^{-\frac{\left(\ln d-M_{\ln d}\right)^{2}}{2 \sigma_{\ln d}}},
$$

where $M_{\text {lnd }}$ and $\sigma_{\ln d}$ are expected value and standard deviation of the logarithm of the NP diameter, respectively.

With the use of an experimental distribution in size, one can predict the density of a normal or lognormal distribution. With a particle amount more than 50, the probability density with the accuracy of the experiment corresponds to the general population, which means a sufficient statistical sampling. Figures 3-5, $a$ show the experimental distribution of the diameters of the three NiCo, NiCo@GNP and Ni$\mathrm{Co} @ \mathrm{SiO}_{2}$ systems. $\mathrm{NiCo} @ \mathrm{SiO}_{2}$ and $\mathrm{NiCo} @ G N P$ systems have a more even distribution, albeit they are significantly different from the val- 


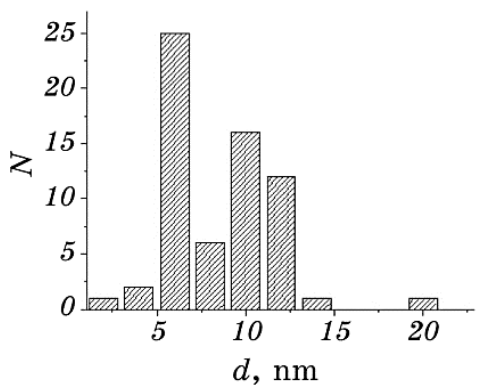

$a$

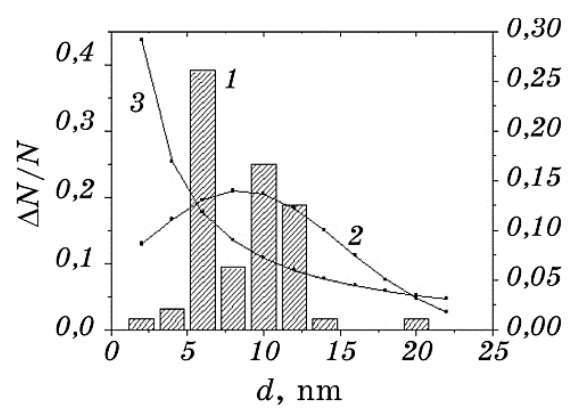

$b$

Fig. 3. $a$-the NP distribution by the diameters for the NiCo system; $b$-the polygon of the relative frequencies of the NP diameters, and the probability density calculated by the lognormal distribution 1 by Eq. (1) of the NP ensemble of NiCo particles and by the normal distribution 2 by Eq. (2).

ues of the largest and smallest bore diameters.

Curves obtained in Fig. $3-5, b$ show that the NiCo particles are distributed by diameters closer to the normal distribution, the maximum values of NiCo@GNP are closer to the lognormal, and $\mathrm{NiCo@} \mathrm{SiO}_{2}$ in accordance with the normal. An analysis of form of the distribution of nanoparticles can serve as a means for testing hypotheses regarding the nature of their growth in the process of chemical condensation [30]. In most cases, formation of a low frequency is followed by two processes: sequential and/or parallel growth. In the case of the random nature of the interactions between the NP, with the parallel growth (without interaction between the crystals), it is likely that the distribution of the NP in size is normal (Gaussian), while in the sequential manner, it is lognormal [31].

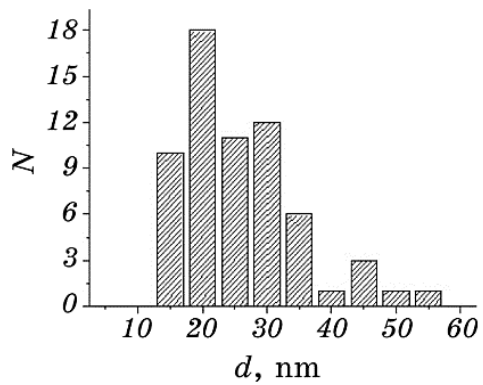

$a$

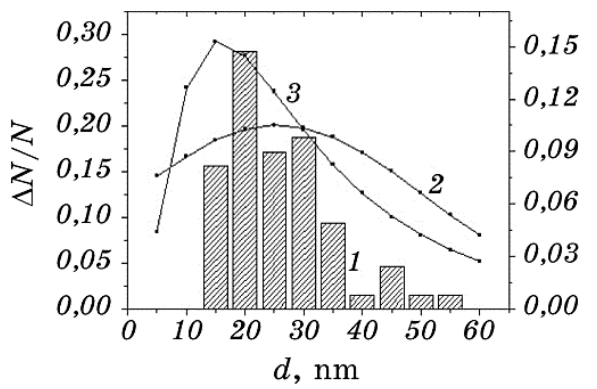

$b$

Fig. 4. $a$-the distribution by diameters, $b$-the polygon of relative frequencies of diameters and density of probability calculated by Eq. (1) for the NP ensemble of NiCo @ GNP $(N=63)$ : 1 -lognormal, 2 -normal distribution of the NiCo bulk and NiCo nanoparticles in the NiCo@GNP nanocomposite. 


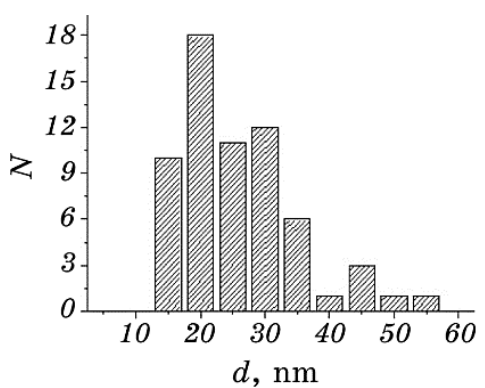

$a$

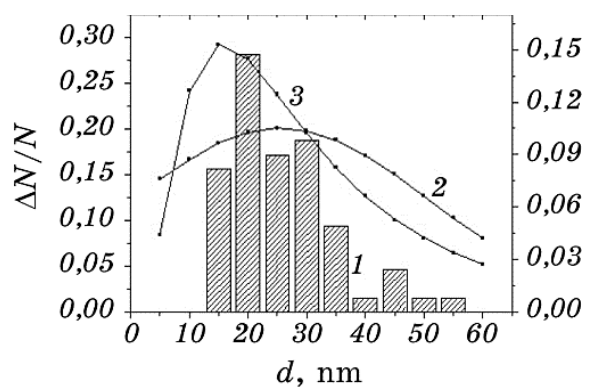

$b$

Fig. 5. $a$-the distribution by diameters, $b$-the polygon of relative frequencies of diameters and density of probability calculated by Eq. (1) of the Ni$\mathrm{Co} @ \mathrm{SiO}_{2} \mathrm{NP}$ ensemble $(N=64)$. 1 -lognormal, 2 -normal distribution of the $\mathrm{NiCo}$ bulk and $\mathrm{NiCo} @ \mathrm{SiO}_{2}$ nanocomposite.

For the system of magnetosensitive $\mathrm{SiO}_{2} / \mathrm{Fe}_{3} \mathrm{O}_{4}$ nanocomposites, it was shown [25,32] that artificial nucleation can produce magnetic material with an average crystallite size of $5-8 \mathrm{~nm}$ and a value of a specific surface area that is $2-3$ times higher than the corresponding value for magnetite obtained by the Elmor's method.

Stabilization of magnetic NP on primary particles can increase the stability of nanocomposite system particles. NiCo fixed on the surface of $\mathrm{SiO}_{2}$ and GNP or incorporated into the space between these particles have spatial barriers to aggregation among themselves, but remain accessible to other reagents of the existing system. It is important that they can not only store their basic physical and chemical characteristics, but also acquire new ones.

By the method of magnetic granulometry [27], which is based on the comparison of the experimental and Langevin magnetization curves with given laws of particle-size distribution and their magnetic parameters, in particular, the magnetization of saturation of the particle material and the thickness of degaussed layer, according to the experimental magnetization curve of the NSC, they were found to be in the size distribution of the NP. For the analysis of magnetization curves, the known equation [28, 29]

$$
\frac{\sigma^{N C P}(H)}{\sigma_{s}^{N C P}}=\left(\sum_{i=1}^{k} n_{i} D_{i}^{3}\right)^{-1} \sum_{i=1}^{k} n_{i}\left(D_{i}-2 \varepsilon\right)^{3} L\left(\frac{M_{s}^{\text {bulk }} H}{k_{B} T} \frac{\pi}{6}\left(D_{i}-2 \varepsilon\right)^{3}\right),
$$

where $\sigma^{N C P}(H), \sigma_{s}^{N C P}$ - the NP specific magnetization in the applied field of intensity $H$ and the specific magnetization of the NP saturation, respectively, $M_{s}^{\text {bulk }}$ - the magnetization of the saturation of the massive nickel crystal; $D_{i}, n_{i}$ - the mean diameter and the number of $\mathrm{NP}$ in the $i$-th range of the variational row of diameters; $k$-number of 


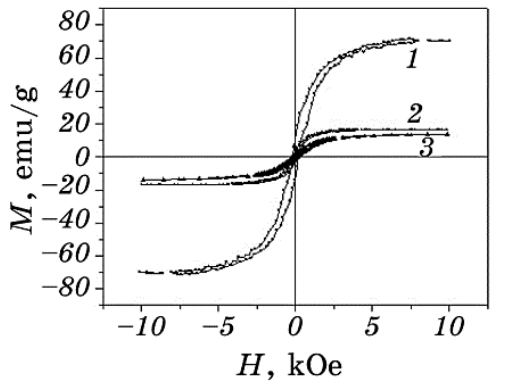

$a$

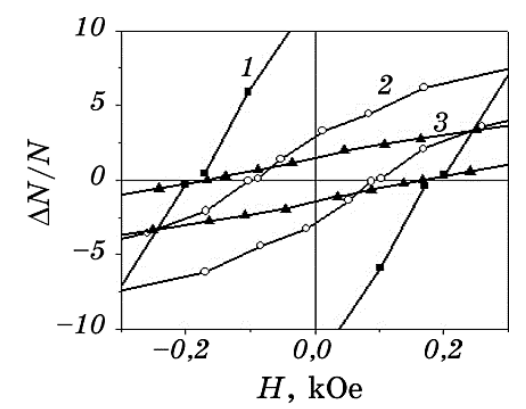

$b$

Fig. 6. Loops of hysteresis (a) of the NiCo (1), NiCo@GNP (2), NiCo@ $\mathrm{SiO}_{2}(3)$ samples; the central part of the hysteresis $(b)$.

intervals; $\varepsilon$ - the thickness of the surface NP with nonlinear magnetic moments; $L(\xi) \equiv \operatorname{cth} \xi-1 / \xi$-Langevin function; $k_{B}$-Boltzmann constant; $T$-absolute temperature.

In Figure 6, it is evident that the magnetization of NiCo@GNP and $\mathrm{NiCo} @ \mathrm{SiO}_{2}$ samples is similar in the application of magnetic field of 10 kOe. The magnetization of a NiCo sample is much higher in the magnetization of composite specimens, which, assuming the same lowfrequency size for the $\mathrm{NiCo} @ \mathrm{SiO}_{2}$ system, indicates the content of the nonmagnetic component of the NP in the composite.

Saturation magnetization depends on the size of particles. The ratio of saturation magnetization (Table 2) for the NiCo and $\mathrm{NiCo@} \mathrm{SiO}_{2}$ samples (exactly these samples can be compared, since they have approximately the same particle sizes $), \sigma_{s}\left(\mathrm{NiCo} @ \mathrm{SiO}_{2}\right) / \sigma_{s}(\mathrm{NiCo})$, is about $24 \%$ (by mass) of magnetic nanoparticles in the $\mathrm{NiCo} @ \mathrm{SiO}_{2}$ composite. For larger NiCo@GNP particles, a comparison with literature data [33] shows that the mass fraction of magnetic particles is about $20 \%$.

The residual magnetization of the $\mathrm{NiCo@} \mathrm{SiO}_{2}$ sample (Fig. 6, b) is twice as low as the NiCo nanoparticles output, and is twice as low as the coercive force, so the $\mathrm{NiCo} @ \mathrm{SiO}_{2}$ particles are more easily magnetized than the NiCo NP. The above-mentioned characteristics describe the ensemble of particles, not each separately.

TABLE 2. Magnetic characteristics of the NiCo and BNC nanoparticles on their basis.

\begin{tabular}{c|cccc}
\hline Pattern & $H_{c}, \mathrm{Oe}$ & $\sigma(10 \mathrm{kOe}), \mathrm{Gs} \cdot \mathrm{cm}^{3} / \mathrm{g}$ & $\sigma_{s}, \mathrm{Gs} \cdot \mathrm{cm}^{3} / \mathrm{g}$ \\
\hline $\mathrm{NiCo}$ & $178( \pm 1 \%)$ & $71.1( \pm 2.5 \%)$ & $73.2( \pm 2.5 \%)$ \\
$\mathrm{NiCo} @ \Gamma \mathrm{H} \Pi$ & $164( \pm 1 \%)$ & $13.8( \pm 2.5 \%)$ & $14.2( \pm 2.5 \%)$ \\
$\mathrm{NiCo@SiO} \mathrm{Si}_{2}$ & $91( \pm 1 \%)$ & $16.8( \pm 2.5 \%)$ & $17.3( \pm 2.5 \%)$ \\
\hline
\end{tabular}




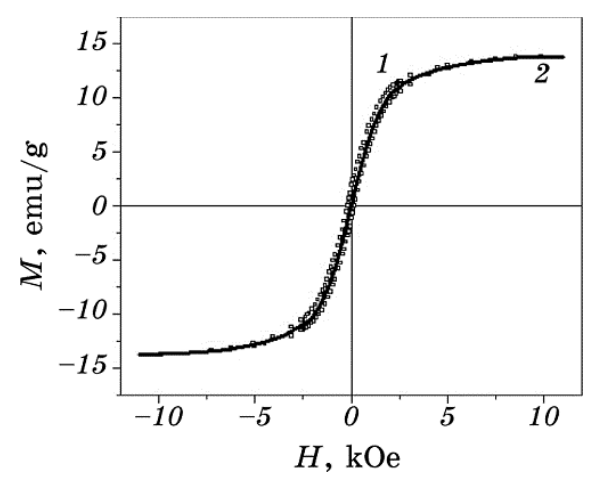

Fig. 7. 1 - the hysteresis loop of the NiCo@GNP sample obtained experimentally, 2-the theoretical curve obtained by Eq. (4) for the low NiCo@GNP $(N=63)$ with parameters $M_{\ln V}=8.61774$ and $\sigma_{\ln V}=1.03888$.

In one-domain state, the prevailing mechanism of reversal is a process of coherent rotation of magnetic moments, which is hindered by crystallographic anisotropy and anisotropy of form of a particle. The maximum coercive force of reversal of the ensemble of chaotically oriented noninteracting particles with uniaxial anisotropy can be represented as two terms (neglecting the anisotropy of mechanical stresses):

$$
H_{c}={ }_{K} H_{c}+{ }_{N} H_{c}=0.64 K / I_{s}+0.479\left(N_{a}-N_{R}\right) I_{s},
$$

where ${ }_{K} H_{c},{ }_{N} H_{c}$ are maximum value of the reciprocal field caused by the presence of crystallographic anisotropy and the component caused by the anisotropy of form [32], respectively; $K$ is the anisotropy constant.

In approximation of a spherical particle, $N_{a}-N_{R}$, the second term of Eq. (4), turns to zero. An analysis of the hysteresis loops of composites taking into account Eq. (4) indicates the possibility of determining the value of the constant of the crystallographic anisotropy of the NiCo NP, which characterizes an ability of the material to remagnetization.

$$
I_{s}=\rho \sigma_{s}
$$

where $\rho$ is the density of the material, $\sigma_{s}$ is the specific magnetization of saturation, from where $K=H \rho \sigma_{s}, K=1.8 \cdot 10^{5} \mathrm{erg} / \mathrm{cm}^{3}$. The constants of anisotropy for $\mathrm{Ni}$ and $\mathrm{Co}$ are equal to $-0.5 \cdot 10^{5} \mathrm{erg} / \mathrm{cm}^{3}$ and $45 \cdot 10^{5} \mathrm{erg} / \mathrm{cm}^{3}$ [33], respectively. Therefore, the calculated value is within the specified limits.

\section{CONCLUSIONS}

The NiCo, NiCo on the surface of graphene (NiCo@GNP) and NiCo on 
the surface of silica dioxide $\left(\mathrm{NiCo} @ \mathrm{SiO}_{2}\right)$ nanoparticles were obtained by chemical precipitation from a solution of hydrazine hydride. The conducted PEM and x-ray studies showed the presence of phases of nanometer-size composites.

The crystallographic anisotropy constant for the NiCo nanoparticles and the mass content of magnetic nanoparticles in the $\mathrm{NiCo} @ \mathrm{SiO}_{2}$ and NiCo@GNP composites are equal to 24 and 20\%, respectively.

The method of magnetic granulometry has established that the NiCo and $\mathrm{NiCo} @ \mathrm{SiO}_{2}$ particles have a normal size distribution, and NiCo@GNP is lognormal, which indicates a different mechanism of growth. For NiCo and NiCo@ $\mathrm{SiO}_{2}$, a parallel crystal growth is typical, and for NiCo@GNP, successively due to the influence of surface of a matrix. Study of the distribution of size of synthesized particles shows that the nature of growth of crystals can be controlled changeably.

\section{REFERENCES}

1. G. Sharma, M. Naushad, A. Kumar, S. Devi, and M. R. Khan, Iran. Polym. J., 24: 1003 (2015).

2. G. Sharma, D. Kumar, A. Kumar, A. H. Al-Muhtaseb, D. Pathania, M. Naushad, and G. T. Mola, Mater. Sci.Eng. C, 71: 1216 (2017).

3. G. Sharma, A. Kumar, Sh. Sharma, Mu. Naushad, R. P. Dwivedi, Z. A. ALOthman, and G. T. Mola, Journal of King Saud University - Science (2017).

4. S. M. Hamidi, B. Mosaeii, M. Afsharnia, A. Aftabi, and M. Najafi, J. Magn. Magn. Mater., 417: 130 (2016).

5. Y. Han, W. Li, M. Zhang, and K. Tao, Chemosphere, 72: 53 (2008).

6. B. Habibi and S. Ghaderi, Int. J. Hydrogen Energy, 40, Iss. 15: 5115 (2015).

7. M. Motlak, N. A. Barakat, M. S. Akhtar, A. M. Hamza, B. Kim, C. Sang, K. Abdelrazek, and A. A. Almajid, Electrochim. Acta, 160: 138 (2015).

8. V. Dao, Y. Choi, K. Yong, L. L. Larina, O. Shevaleevskiy, and H. Choi, J. Power Sources, 274: 831 (2015).

9. M. Cui, J. Huang, Y. Wang, Y. Wu, and X. Luo, Biosens. Bioelectron., 68: 563 (2015).

10. C. Kung, P. Lin, F. John, Y. Xue, and X. Yu, Biosens. Bioelectron., 52: 1 (2014).

11. S. Awasthi, S. K. Pandey, A. Juyal, C. P. Pandey, and K. Balani, J. Alloys Compd., 711: 15 (2017).

12. R. Ahmad, A. S. Qureshi, L. Li, J. Bao, X. Jia, Y. Xu, and X. Guo, Colloids Surf. B: Biointerfaces, 143: 490 (2016).

13. S. Akamaru, M. Inoue, Y. Honda, A. Taguchi, and T. Abe, Jpn. J. Appl. Phys., 51, No. 6R: 065201 (2012).

14. M. Maicas, M. Sanz, H. Cui, C. Aroca, and P. Sánchez, J. Magn. Magn. Mater., 322: 3485 (2010).

15. G. Saito, S. Hosokai, T. Akiyama, S. Yoshida, S. Yatsu, and S. Watanabe, J.Phys. Soc.Jpn., 79: 083710 (2010).

16. P. Kalita, J. Singh, M. K. Singh, P. R. Solanki, G. Sumana, and B. D. Malhotra, Appl. Phys. Lett., 100: 093702 (2012). 
17. P. Calandra, Mater. Lett., 63: 2416 (2009).

18. I. Gonzalez, J. C. De Jesus, E. Cañizales, B. Delgado, and C. Urbina, J. Phys. Chem. C, 116: 21577 (2012).

19. T. Bala, R. D. Gunning, M. Venkatesan, J. F. Godsell, S. Roy, and K. M. Ryan, Nanotechnology, 20: 415603 (2009).

20. Y. Yamauchi, T. Itagaki, T. Yokoshima, and K. Kuroda, Dalton Trans., 41: 1210 (2012).

21. X. Wu, Z. Zhang, C. Xia, B. Chen, and X. Min, J.Alloys Compd., 718: 15 (2017).

22. E. Motamedi, M. Talebi Atouei, and M. Z. Kassaee, Materials Research Bulletin, 54: 34 (2014).

23. X. Lv, J. Guo, C. Zhao, Y. Wei, J. Zhang, Z. Wu, and C. Gong, Mater. Lett., 201: 43 (2017).

24. P. V. Lapsina, Nanostrukturirovanye Poroshki Ni, Co i Sistemy Ni-Co, Poluchenhye Vosstanovleniem Kristallicheskikh Karbonatov Vodnym Rastvorom Gidrazin Gidrata [Nanostructured Powder of Ni, Co and Ni-Co System Obtained by Recovery of Crystalline Carbonates by Water Hydrazine Hydrate Solution] (Thesis of Disser. for Dr. Chem. Sci.) (Kemerovo: 2013) (in Russian).

25. M. V. Borysenko, V. M. Bogatyrov, I. V. Dubrovin, M. V. Abramov, M. V. Gayevaya, and P. P. Gorbik, Fiziko-Khimiya Nanomaterialov $i$ Supramolekulyarnykh Struktur [Physicochemistry of Nanomaterials and Supramolecular Structures] (Kiev:2007) (in Russian).

26. C. P. Bean and J. D. Livingston, J.Appl. Phys., 30: 120S (1959).

27. A. Yu. Olenin, Rossiyskie Nanotekhnologii, 7, Nos. 5-6: 53 (2012) (in Russian).

28. M. M. Labushev, Matematicheskie Metody i Modeli pri Reshenii Geologicheskikh Zadach na EhVM [The Mathematical Methods and Models for Solving Geological Problems on a Computer] (Krasnoyarsk: 2007) (in Russian)

29. V. M. Bogatyrov, M. V. Borysenko, I. V. Dubrovin, M. V. Abramov, M. V. Galaburda, and P. P. Gorbyk, Nanomaterials and Supramolecular Structures : Physics, Chemistry, and Applications (Eds. A. P. Shpak and P. P. Gorbyk) (Dordrecht,Netherlands: Springer: 2009), p. 159.

30. C. P. Bean and I. S. Jacobs, J.Appl. Phys., 27: 1448 (1956).

31. R. Kaiser and G. Miscolczy, J.Appl. Phys., 41, No. 3: 1064 (1970).

32. E. E. Bibik, B. Ya. Matyrgulin, Yu. L. Raykher, and M. I. Shliomis, Magnitnaya Gidrodinamika, 68, No. 1: 68 (1973) (in Russian).

33. B. D. Cullity and C. D. Graham, Introduction to Magnetic Materials (Wiley-IEEE Press: 2009). 